ISSN 1678-3921

Journal homepage: www.embrapa.br/pab

For manuscript submission and journal contents, access: www.scielo.br/pab

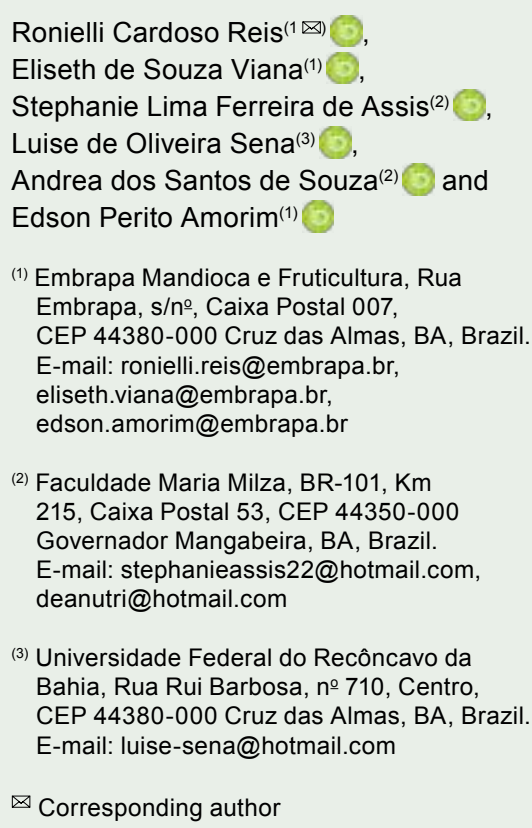

(3) Universidade Federal do Recôncavo da Bahia, Rua Rui Barbosa, no 710, Centro, CEP 44380-000 Cruz das Almas, BA, Brazil. E-mail: luise-sena@hotmail.com

$\bowtie$ Corresponding author

Received

February 21, 2019

Accepted

October 31, 2019

How to cite

REIS, R.C.; VIANA, E. de S.; ASSIS, S.L. de; SENA, L. de O.; SOUZA, A. dos S. de; AMORIM, E.P. Promising green banana and plantain genotypes for making flour. Pesquisa Agropecuária Brasileira, v.54, e01303, 2019. DOI: https://doi.org/10.1590/S1678-3921. pab2019.v54.01303.

\section{Promising green banana and plantain genotypes for making flour}

\begin{abstract}
The objective of this work was to characterize banana and plantain genotypes and to identify the most promising for flour production. Sixteen plantain genotypes and four banana cultivars were evaluated for dry matter content and flour yield. The obtained flours were characterized by color ( $\mathrm{L}^{*}$, $\mathrm{C}^{*}$, and $\mathrm{h}^{*}$ ) and by moisture, total and resistant starch, ash, protein, lipid, and fiber contents. A low genetic variability was observed among plantains for the evaluated physicochemical and nutritional characteristics. The Chifre de Vaca, Comprida, Terra Ponta Aparada, Trois Vert, Terrinha, and Terra Maranhão plantains showed the highest dry matter contents and flour yield. The Chifre de Vaca, Comprida, Curare Enano, Mongolo, Trois Vert, and Terra Maranhão plantains and the 'Pacovan', 'Prata Anã', 'BRS Platina', and 'BRS SCS Belluna' bananas had resistant starch levels above $60 \%$. The flour from 'BRS SCS Belluna' presented the highest contents of ash, protein, and fiber, as well as the lowest caloric value. Considering dry matter content, flour yields, and resistant starch, the Chifre de Vaca, Comprida, Trois Vert, and Terra Maranhão plantains are the best options to produce flour. From a nutritional point of view, 'BRS SCS Belluna' is a good option for producing flour rich in resistant starch, mineral, protein, and fiber contents.
\end{abstract}

Index terms: Musa, nutrition, prebiotic, resistant starch, starch.

\section{Genótipos promissores de bananas e plátanos verdes para elaboração de farinha}

Resumo - O objetivo deste trabalho foi caracterizar genótipos de bananas e plátanos e identificar os mais promissores para a fabricação de farinha. Dezesseis genótipos de plátanos e quatro cultivares de banana foram avaliados quanto ao teor de matéria seca e ao rendimento em farinha. As farinhas obtidas foram caracterizadas quanto à cor $\left(\mathrm{L}^{*}, \mathrm{C}^{*} \mathrm{e} \mathrm{h}^{*}\right)$ e aos teores de umidade, amido total e resistente, cinzas, proteínas, lipídeos e fibras. Observou-se baixa variabilidade genética entre os plátanos para as características físico-químicas e nutricionais avaliadas. Os plátanos Chifre de Vaca, Comprida, Terra Ponta Aparada, Trois Vert, Terrinha e Terra Maranhão apresentaram maiores teores de matéria seca e melhor rendimento em farinha. Os plátanos Chifre de Vaca, Comprida, Curare Enano, Mongolo, Trois Vert e Terra Maranhão e as bananas 'Pacovan', 'Prata Anã', 'BRS Platina' e 'BRS SCS Belluna' apresentaram teores de amido resistente acima de $60 \%$. A farinha de 'BRS SCS Belluna' apresentou maiores teores de cinzas, proteína e fibras, bem como menor valor calórico. Ao se considerar matéria seca, rendimento em farinha e teor de amido resistente, os plátanos Chifre de Vaca, Comprida, Trois Vert e Terra Maranhão são as melhores opções para produzir farinha. Do ponto de vista nutricional, a banana 'BRS SCS Belluna' é uma boa opção para produção de farinha com altos teores de amido resistente, minerais, proteínas e fibras.

Termos para indexação: $M u s a$, nutrição, prebiótico, amido resistente, amido. 


\section{Introduction}

Bananas and plantains belong to the genus Musa and result from the intra- and interspecific hybridizations of two species: Musa acuminata Colla (genome A) and Musa balbisiana Colla (genome B). Dessert bananas (AA, AAA, and AAB genomic groups) are consumed raw at several stages of maturity (Gibert et al., 2009), whereas plantains, which are part of the AAB group, are not palatable when raw, being consumed cooked, fried, or as a flour due to their high starch content even when ripe. In Brazil, plantains, known as "banana-daterra", differ from dessert bananas due to their larger and starchier fruits that are generally palatable only after cooking (Daniells, 2003). Although plantains are important in the country, only three varieties are available to farmers: Terra Maranhão, Terrinha, and D’Angola (Gonçalves et al., 2018).

Recently, green banana has been considered a new food ingredient, and several studies have suggested that it is consumption has a beneficial effect on health, since it is the unprocessed food richest in resistant starch (RS) or in the fraction of starch that behaves physiologically as soluble fiber (Fuentes-Zaragoza et al., 2010).

To include green bananas in human diet, the best option is in the form of flour, which can be directly consumed or used in baked, dietetic, and baby food products (Vernaza et al., 2011). Its production technology is simple and increases banana shelf life and value, it is easy to transport and store, and it also creates opportunities for the rural agro-industries (Yani et al., 2013).

Compared with traditional fibers present in whole grains, bran and fruit, RS in green banana flour has better sensory attributes, such as appearance, texture and flavor of the end product, which is positive from a commercial perspective (Fuentes-Zaragoza et al., 2010). Green banana flour is also rich in proteins, fibers, and minerals, such as potassium, phosphorus, magnesium, copper, manganese, and zinc (Borges et al., 2009). When evaluating 23 cultivars from Colombia, Gibert et al. (2009) found contents of 2.10 to $4.88 \%$ protein, 1.8 to $5.0 \%$ total fiber, and 2.3 to $4.3 \%$ ash contents.

Some cultivars have already been used to obtain green banana flour and food products, including Prata Anã, Gros Michel (Daramola \& Osanyinlusi, 2006), and different ones from the Cavendish subgroup
(Menezes et al., 2011; Segundo et al., 2017). Several studies have shown that the RS contents of these flours vary according to the banana genotype. Vatanasuchart et al. (2009), for example, reported values from 52.2 to $68.1 \%$ for RS contents of the flour from 11 cultivars from Thailand, whereas Thakorjal et al. (2010) observed 29.58 to $46.24 \%$ RS in the flour from five cultivars from Micronesia. Agama-Acevedo et al. (2012) found from 65.3 to $91.9 \%$ RS extracted from four cultivars from Mexico, while Mesquita et al. (2016) verified contents of 65.91 to $82.67 \%$ RS for five banana varieties cultivated in Brazil.

The results of these studies show that the genotype directly influences the nutritional quality and RS content of the obtained green banana flours; however, few works have explored the potential of plantains for flour production. The genetic variability of characteristics of interest is fundamental for genetic improvement programs, and the physicochemical and nutritional characterization of plantain germplasms can provide useful information to identify genotypes with different use potentials.

The objective of this work was to characterize banana and plantain genotypes and to identify the most promising for flour production.

\section{Materials and Methods}

The following genotypes were evaluated: 12 plantain genotypes from the germplasm collection of Empresa Brasileira de Pesquisa Agropecuária, i.e., Chifre de Vaca, Comprida, Curare Enano, Mongolo, Pinha, Red Yade, Samura B., Terra Anã Branca, Terra Ponta Aparada, Terra Sem Nome, Tipo Velhaca, and Trois Vert; 3 commercial Brazilian plantains, Terra Maranhão, D’Angola, and Terrinha; and 5 commercial Brazilian dessert bananas, 'BRS SCS Belluna', 'BRS Platina', 'Grande Naine', 'Pacovan', and 'Prata Anã'. The study was conducted in the experimental field located in the municipality of Cruz das Almas, in the state of Bahia, Brazil $\left(12^{\circ} 40^{\prime} 19^{\prime \prime} \mathrm{S}, 39^{\circ} 06^{\prime} 22^{\prime} \mathrm{W}^{\prime}\right.$, at $220 \mathrm{~m}$ above sea level), between October 2013 and December 2015. The climate is classified as Aw to Am, tropical hot and humid, according to Köppen's classification, with an average annual temperature of $24.5^{\circ} \mathrm{C}$, relative humidity of $80 \%$, and rainfall of 1,250 $\mathrm{mm}$ (Gonçalves et al., 2018). 
The experiment was conducted in a completely randomized design with three experimental replicates, corresponding to the fruits of three different plants.

Bunches were harvested and processed in maturation stage 1 , when the peel was completely green. Fruits were peeled and cut into 4-to-5-mm thick slices and immersed in an aqueous solution of $100 \mathrm{mg} \mathrm{L}^{-1}$ citric acid and $300 \mathrm{mg} \mathrm{L}^{-1}$ ascorbic acid for 10 to $15 \mathrm{~min}$ to prevent pulp darkening. The drying process was conducted with a convection dryer, at $50^{\circ} \mathrm{C}$ and an air velocity of $1.5 \mathrm{~m} \mathrm{~s}^{-1}$, until the moisture content was between 5 and $10 \%$ wet weight. The dehydrated slices were ground with a knife mill with 30-mesh sieves, packed in vacuum-sealed polyethylene bags, and stored frozen until analysis.

Yields were calculated based on the weight of fruits with peel (FYWP). For color evaluation, whiteness/ darkness $\left(\mathrm{L}^{*}\right)$, chroma/color intensity $\left(\mathrm{C}^{*}\right)$, and hue angle ( $\left.\mathrm{h}^{*}\right)$ were determined with a colorimeter using illuminant D65 ( $\mathrm{z}=93.6 ; \mathrm{x}=0.3133 ; \mathrm{y}=0.3195)$.

RS was obtained according to Goñi et al. (1996), and total starch was quantified based on the method of Rickard \& Behn (1987). Moisture, ash, and protein contents were determined as proposed by Instituto Adolfo Lutz (Zenebon et al., 2008); dry matter, by the difference between 100 and moisture percentage; and lipid content, by the method of Bligh \& Dyer (1959). The fiber content analysis was based on the AOAC 985.29 method (Latimer \& George, 2012); for the obtained data, only one sample of each treatment was evaluated and no statistical analysis was performed. Carbohydrate content was determined by the difference between 100 and the sum (percentage) of moisture, ash, lipid, total protein, and nutritional fiber values. The total caloric value (TCV) was calculated based on flour composition, using the following conversion factors: $4 \mathrm{kcal} \mathrm{g}^{-1}$ for proteins, $4 \mathrm{kcal} \mathrm{g}^{-1}$ for carbohydrates, and $9 \mathrm{kcal} \mathrm{g}^{-1}$ for lipids.

Data were subjected to the univariate analysis of variance, and averages were grouped by the ScottKnott test, at $5 \%$ probability. The multivariate analysis was conducted using the unweighted pair-group average method from the Euclidean distance, and the principal component analysis using a correlation matrix. The statistical analyses were carried out with the Statistica software (TIBCO Software Inc., Palo Alto, CA, USA).

\section{Results and Discussion}

The highest dry matter content was found for plantains, with an average of $40.40 \%$, which did not differ among each other (Table 1). The 'BRS SCS Belluna', 'BRS Platina', and 'Grande Naine' dessert bananas had the lowest DM content, with an average of $26.36 \%$. These results are in alignment with those of Gibert et al. (2009), who found values from $24.6 \%$ for dessert hybrids to $41.1 \%$ for plantains.

Dry matter content can directly influence flour yield and, therefore, is an important parameter that must be considered when choosing the raw material for flour production, directly reflecting in the producer's profit. The Chifre de Vaca, Comprida, Terra Ponta Aparada, and Trois Vert plantains have high FYWP values between 24.31 and $27.71 \%$, similar to those of 27.19 and $25.17 \%$, respectively, of the Terrinha and Terra Maranhão commercial plantains (Table 1).

The flour obtained from the 'Grande Naine' dessert banana had the lowest $\mathrm{L}^{*}$ values, and, therefore, was darker than the others (Table 1). This result is an indicative that the browning of green banana flours is due to genotype characteristics and maturity rate, as well as to the used processing methods (Yani et al., 2013). Since, in the present study, all genotypes were processed at the same maturity rate and with the same processing parameters, the difference in $L^{*}$ values is due to genotype. Even at the green stage of maturity, the sugars in the fruits from 'Grande Naine' could react (Maillard reaction) with amino acids during the dehydration process, producing dark pigments (Yani et al., 2013). Flours obtained from the other genotypes presented more whiteness and had an average $\mathrm{L}^{*}$ of 81.76 (Table 1), higher to that of 78.12 observed by Vernaza et al. (2011) for the flour from a commercial banana. This characteristic can favor the use of these flours for the production of different products, since it does not greatly change their color, having little visual impact on consumer preference. These results corroborate those of Savlak et al. (2016), who evaluated green banana flours with different particle sizes, finding $\mathrm{L}^{*}$ between $80.18(501-700 \mu \mathrm{m})$ and 85 $(\mu \mathrm{m}<212)$. Anyasi et al. (2015) reported similar values between 79.39 and 85.29 for green banana flours.

No significant differences were found among $h^{*}$ values, with an average was 90.65 , showing that all the flours were yellow. Regarding $\mathrm{C}^{*}$, the flours from the Comprida and Terra Ponta Aparada plantains 
did not differ significantly from those from the Terrinha and Terra Maranhão commercial plantains, being characterized by a more intense yellow color (Table 1). This stronger color intensity is related to the pulp color of the genotypes, and an increase in $\mathrm{C}^{*}$ is directly associated with a greater concentration of pigments in food (Wrolstad \& Smith, 2010). According to Borges et al. (2019), there is a positive correlation between the orange/yellow color of plantain pulp and carotenoid content, suggesting that genotypes with a high value of $C^{*}$ in their pulp present a higher content of pro-vitamin compounds. Probably, the Comprida, Terra Ponta Aparada, Terrinha, and Terra Maranhão genotypes, which produced yellower flours, have more total carotenoids than the others, being interesting from a nutritional point of view.
There was no significant difference among genotypes for total starch contents, with an average of $83.98 \%$ (Table 2). Similar results of $80.02 \%$ were reported by Hoffmann Sardá et al. (2016) for green banana flour from a cultivar of the Cavendish subgroup; however, Menezes et al. (2011) obtained a lower value of $76.77 \%$ for flours from the same cultivar. Due to their high starch contents, green banana flours can also be used as alternative starch sources, replacing corn, rice, and wheat (Yani et al., 2013).

A great variability in RS content, varying from 21.15 to $70.06 \%$, was observed among the assessed green banana flours (Table 2). The RS content of most of the genotypes evaluated in the present study is similar to that of 50.7 to $68.1 \%$ obtained by Vatanasuchart et al. (2009), who analyzed flours from 11 banana cultivars. The flours from the Curare Enano and Mongolo

Table 1. Dry matter, flour yields based on the weight of fruits with peel (FYWP) on a dry basis percentage, and color attributes of green banana and plantain (Musa spp.) flours ${ }^{(1)}$.

\begin{tabular}{|c|c|c|c|c|c|c|}
\hline Group & Genotype & Dry matter & FYWP & $\mathrm{L}^{*}$ & $\mathrm{C}^{*}$ & $\mathrm{~h}^{*}$ \\
\hline \multirow{12}{*}{$\begin{array}{l}\text { Plantains from } \\
\text { germplasm } \\
\text { collection }\end{array}$} & Chifre de Vaca & $44.67 \mathrm{a}$ & $24.31 \mathrm{a}$ & $82.25 \mathrm{a}$ & $15.80 \mathrm{~b}$ & 92.01 \\
\hline & Comprida & $39.20 \mathrm{a}$ & $27.71 \mathrm{a}$ & $82.15 \mathrm{a}$ & $21.43 \mathrm{a}$ & 89.90 \\
\hline & Curare Enano & $42.08 \mathrm{a}$ & $18.48 \mathrm{~b}$ & $81.82 \mathrm{a}$ & $12.34 \mathrm{c}$ & 90.59 \\
\hline & Mongolo & $42.06 \mathrm{a}$ & $20.85 b$ & $81.02 \mathrm{a}$ & $12.82 \mathrm{c}$ & 90.90 \\
\hline & Pinha & $39.75 \mathrm{a}$ & $20.89 b$ & $81.82 \mathrm{a}$ & $13.41 \mathrm{c}$ & 92.35 \\
\hline & Red Yade & $40.32 \mathrm{a}$ & $20.60 \mathrm{~b}$ & $82.21 \mathrm{a}$ & $15.11 \mathrm{~b}$ & 91.26 \\
\hline & Samura B. & $35.94 a$ & $19.69 b$ & $81.23 \mathrm{a}$ & $12.35 \mathrm{c}$ & 90.10 \\
\hline & Terra Anã Branca & $41.94 \mathrm{a}$ & $20.10 \mathrm{~b}$ & $81.51 \mathrm{a}$ & $13.12 \mathrm{c}$ & 90.44 \\
\hline & Terra Ponta Aparada & $40.00 \mathrm{a}$ & $27.08 \mathrm{a}$ & $81.69 \mathrm{a}$ & $21.87 \mathrm{a}$ & 89.80 \\
\hline & Terra Sem Nome & $40.52 \mathrm{a}$ & $18.05 b$ & $82.33 \mathrm{a}$ & $11.25 \mathrm{c}$ & 90.96 \\
\hline & Tipo Velhaca & $42.33 \mathrm{a}$ & $19.29 b$ & $81.58 \mathrm{a}$ & $12.66 \mathrm{c}$ & 90.24 \\
\hline & Trois Vert & $37.60 \mathrm{a}$ & $25.32 \mathrm{a}$ & $82.00 \mathrm{a}$ & $16.77 b$ & 91.82 \\
\hline \multirow{3}{*}{$\begin{array}{l}\text { Commercial } \\
\text { Brazilian } \\
\text { plantains }\end{array}$} & Terra Maranhão & $37.60 \mathrm{a}$ & $25.17 \mathrm{a}$ & $82.84 a$ & $19.64 \mathrm{a}$ & 92.32 \\
\hline & D'Angola & $41.56 \mathrm{a}$ & $19.65 b$ & $81.58 \mathrm{a}$ & $12.72 \mathrm{c}$ & 90.91 \\
\hline & Terrinha & $40.43 a$ & $27.19 \mathrm{a}$ & $81.92 \mathrm{a}$ & $20.24 \mathrm{a}$ & 92.00 \\
\hline \multirow{5}{*}{$\begin{array}{l}\text { Commercial } \\
\text { Brazilian } \\
\text { dessert } \\
\text { bananas }\end{array}$} & BRS SCS Belluna & $28.06 \mathrm{c}$ & $17.76 \mathrm{~b}$ & $80.56 a$ & $16.17 \mathrm{~b}$ & 89.51 \\
\hline & BRS Platina & $24.84 \mathrm{c}$ & $14.67 \mathrm{~b}$ & $81.90 \mathrm{a}$ & $13.88 \mathrm{c}$ & 88.83 \\
\hline & Grande Naine & $26.18 \mathrm{c}$ & $17.23 b$ & $77.13 b$ & $12.42 \mathrm{c}$ & 87.84 \\
\hline & Pacovan & $31.92 b$ & $18.70 \mathrm{~b}$ & $82.30 \mathrm{a}$ & $13.36 \mathrm{c}$ & 90.43 \\
\hline & Prata Anã & $31.32 \mathrm{~b}$ & $20.28 b$ & $80.76 a$ & $12.94 \mathrm{c}$ & 90.87 \\
\hline F-value & & $12.80 * *$ & $7.03 * *$ & $7.87 * *$ & $7.67 * *$ & $1.08^{\text {ns }}$ \\
\hline CV (\%) & & 7.51 & 11.42 & 0.89 & 13.75 & 2.14 \\
\hline
\end{tabular}

${ }^{(1)}$ Means followed by equal letters, in the columns, belong to the same group based on the Scott $\&$ Knott test, at $5 \%$ probability. L*, whiteness/darkness; $\mathrm{C}^{*}$, chroma/color intensity; and $\mathrm{h}$, hue angle. ${ }^{* *}$ Significant by the F-test, at $1 \%$ probability. ${ }^{\mathrm{n}}$ Nonsignificant by the F-test, at $5 \%$ probability. 
plantains and of the 'Pacovan' and 'BRS Platina' dessert bananas did not differ and had RS values above $65 \%$. The Chifre de Vaca, Comprida, Trois Vert, and Terra Maranhão plantains and the 'BRS SCS Belluna' and 'Prata Anã' dessert bananas had an average of $60.34 \%$. The RS content of these genotypes was greater than the values from 45.70 to $47.25 \%$ observed by Sarawong et al. (2014) and Vernaza et al. (2011) for commercial green banana flours. The differences between these results and those of the present study are explained by variations in the RS content of flours due to genotype,

Table 2. Total starch (TS), resistant starch (RS), and nonresistant starch (NRS) contents of flours obtained from bananas and plantains (Musa spp.) on a dry basis percentage ${ }^{(1)}$.

\begin{tabular}{|c|c|c|c|c|}
\hline Group & Genotype & TS & $\mathrm{RS}$ & $\mathrm{NRS}^{(2)}$ \\
\hline \multirow{12}{*}{$\begin{array}{l}\text { Plantains from } \\
\text { germplasm } \\
\text { collection }\end{array}$} & Chifre de Vaca & 82.37 & $61.05 \mathrm{~b}$ & $21.97 \mathrm{c}$ \\
\hline & Comprida & 91.40 & $60.79 \mathrm{~b}$ & $30.61 \mathrm{c}$ \\
\hline & Curare Enano & 85.19 & $68.50 \mathrm{a}$ & $16.69 \mathrm{~d}$ \\
\hline & Mongolo & 91.82 & $65.92 \mathrm{a}$ & $25.80 \mathrm{c}$ \\
\hline & Pinha & 84.61 & $53.12 \mathrm{~d}$ & $31.35 \mathrm{c}$ \\
\hline & Red Yade & 86.47 & $43.44 \mathrm{f}$ & $43.76 \mathrm{~b}$ \\
\hline & Samura B. & 85.05 & $52.33 \mathrm{~d}$ & $32.71 \mathrm{c}$ \\
\hline & Terra Ana Branca & 84.76 & $46.26 \mathrm{e}$ & $40.26 \mathrm{~b}$ \\
\hline & Terra Ponta Aparada & 80.66 & $56.13 \mathrm{c}$ & $24.53 \mathrm{c}$ \\
\hline & Terra Sem Nome & 86.97 & $21.15 \mathrm{~g}$ & $65.94 \mathrm{a}$ \\
\hline & Tipo Velhaca & 88.60 & $55.91 \mathrm{c}$ & $32.69 \mathrm{c}$ \\
\hline & Trois Vert & 84.71 & $60.59 b$ & $22.19 \mathrm{c}$ \\
\hline \multirow{3}{*}{$\begin{array}{l}\text { Commercial Bra- } \\
\text { zilian plantains }\end{array}$} & Terra Maranhão & 82.10 & $62.19 \mathrm{~b}$ & $19.91 \mathrm{~d}$ \\
\hline & D’Angola & 90.09 & $46.35 \mathrm{e}$ & $43.74 \mathrm{~b}$ \\
\hline & Terrinha & 83.52 & $40.14 \mathrm{f}$ & $45.68 \mathrm{~b}$ \\
\hline \multirow{5}{*}{$\begin{array}{l}\text { Commercial } \\
\text { Brazilian dessert } \\
\text { bananas }\end{array}$} & BRS SCS Belluna & 74.56 & $59.14 \mathrm{~b}$ & $14.39 \mathrm{~d}$ \\
\hline & BRS Platina & 78.53 & $67.43 \mathrm{a}$ & $11.11 \mathrm{~d}$ \\
\hline & Grande Naine & 73.84 & $51.37 \mathrm{~d}$ & $22.46 \mathrm{c}$ \\
\hline & Pacovan & 84.46 & $70.06 \mathrm{a}$ & $9.30 \mathrm{~d}$ \\
\hline & Prata Anã & 79.84 & $58.30 \mathrm{~b}$ & $23.43 \mathrm{c}$ \\
\hline F-value & & $1.85^{\mathrm{ns}}$ & $49.28 * *$ & $11.59^{* *}$ \\
\hline CV (\%) & & 7.59 & 5.39 & 24.19 \\
\hline
\end{tabular}

${ }^{(1)}$ Means followed by equal letters, in the columns, belong to the same group based on the Scott \& Knott test, at 5\% probability. ${ }^{(2)}$ Calculated as the difference between total starch and resistant starch. **Significant

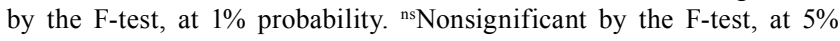
probability. fruit maturation stage, presence or absence of peel, production technique, and processing parameters. Regarding ash content, there were significant differences among the flours from the commercial dessert bananas, with the highest value found for 'BRS SCS Belluna' and 'Grande Naine', with an average of $3.26 \%$ (Table 3). Both of these cultivars are part of the AAA genomic group, whereas BRS SCS Belluna, from Thailand, has no defined subgroup and Grande Naine belongs to the Cavendish subgroup. Mota et al. (2000) reported similar values of 3.5 and 3.0\% for flours from the Nanica and Nanicão cultivars, respectively, and Menezes et al. (2011), of 3.14\% from Nanicão; these cultivars are also part of the Cavendish subgroup. The flours from 'Prata Anã', 'Pacovan', and 'BRS Platina', which have the B genome and belong to the Prata subgroup, did not differ among themselves for ash content, with an average of $2.44 \%$, similar to that of $2.59 \%$ observed by Borges et al. (2009) for 'Prata'. Although plantains have also the B genome, they differed from the others and were characterized by the lowest ash contents, with an average of $1.65 \%$ (Table 3). This result is in alignment with that of Gibert et al. (2009), who found that plantains had lower ash and mineral contents than dessert bananas.

Since the ash and mineral contents of food are directly related, it can be inferred that 'BRS SCS Belluna' and 'Grande Naine' are richer in minerals and, therefore, would be more interesting from a nutritional point of view to bring minerals into the diet. In the present study, considering that all genotypes were cultivated under the same soil and climate conditions, the differences in mineral contents are due to the intrinsic characteristics of each banana genotype.

'BRS SCS Belluna' and 'Grande Naine' had the highest protein contents, with an average of $4.26 \%$ (Table 3), and are good options for producing flour as a source of this nutrient. The flours from 'BRS Platina', 'Prata Anã', and Terra Ponta Aparada presented an average of $3.59 \%$ protein, and the remaining genotypes, an average of $2.96 \%$. These results are similar to those of: $3.54-5.24 \%$ reported by Segundo et al. (2017) for flours from 'Nanica'; $3.60 \%$ by Menezes et al. (2011) for 'Nanicão'; and $4.50 \%$ by Borges et al. (2009) for 'Prata'.

The green banana flours had low lipid contents, from 0.47 to $1.15 \%$, and a fiber content from $4.18 \%$ for Terra Ponta Aparada to $18.79 \%$ for 'BRS SCS Belluna' 
(Table 3). According to Resolução RDC n ${ }^{\circ}$ 54, de 12 de novembro de 2012 (Anvisa, 2012), considering a portion of $50 \mathrm{~g}$, food products with a fiber content above $2.5 \mathrm{~g}$ per portion are considered "sources of fiber" and those with a content above $5.0 \mathrm{~g}$ have a "high fiber content." Based on this legislation, the flours from Terrinha and 'BRS SCS Belluna' stand out and can be considered foods with a "high fiber content", while the other flours (except those from the Terra Ponta Aparada and Terra Maranhão plantains) are "sources of fiber".

The evaluated flours differed significantly regarding carbohydrate content and TCV (Table 3). The flours from the Chifre de Vaca, Curare Enano, D’angola, Terra Ponta Aparada, Tipo Velhaca, Trois Vert, and Terra Maranhão plantains are notable for their highest carbohydrate contents, with an average of $83.55 \%$. Green banana flour is rich in unavailable carbohydrates with a high in vitro fermentability, which makes it a food with potential to promote intestinal health (Menezes et al., 2011). Similar results of 83 to $88 \%$ were obtained by Yani et al. (2013) for flours from different cultivars, of $82.58 \%$ by Vernaza et al. (2011) for commercial flours, and of 81.19 to $82.61 \%$ by Segundo et al. (2017) for flour from 'Nanica'. The flours from the 'BRS SCS Belluna' banana had a lower

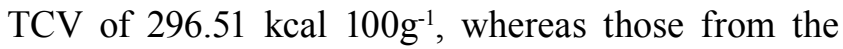
Terra Maranhão and Terra Ponta Aparada plantains had the highest values of 356.58 and $360.17 \mathrm{kcal} 100$ $\mathrm{g}^{-1}$, respectively.

According to Silva et al. (2015), the chemical composition of green banana flours varies with genotype characteristics, maturation stage, processing techniques, and parts of the fruit (peel and pulp) used in the process. In the present study, since all genotypes

Table 3. Nutritional composition and total caloric value (TCV) of green banana and plantain flours (Musa spp.) on a wet basis $^{(1)}$.

\begin{tabular}{|c|c|c|c|c|c|c|c|}
\hline \multirow[t]{2}{*}{ Group } & \multirow[t]{2}{*}{ Genotype } & \multicolumn{5}{|c|}{ Nutritional composition (\%) } & \multirow{2}{*}{$\begin{array}{c}\text { TCV } \\
\left(\mathrm{kcal} 100 \mathrm{~g}^{-1}\right)\end{array}$} \\
\hline & & Ash & Protein & Lipids & Fiber $^{(2)}$ & Carbs & \\
\hline \multirow{12}{*}{$\begin{array}{l}\text { Plantains } \\
\text { from } \\
\text { germplasm } \\
\text { collection }\end{array}$} & Chifre de Vaca & $2.05 \mathrm{c}$ & $2.96 \mathrm{c}$ & $0.67 \mathrm{~b}$ & 5.36 & $82.85 \mathrm{a}$ & $349.28 b$ \\
\hline & Comprida & $1.50 \mathrm{c}$ & $2.94 \mathrm{c}$ & $0.80 \mathrm{~b}$ & 7.36 & $82.25 b$ & $347.95 b$ \\
\hline & Curare Enano & $1.50 \mathrm{c}$ & $2.73 \mathrm{c}$ & $0.72 b$ & 5.85 & $83.74 a$ & $352.62 b$ \\
\hline & Mongolo & $1.75 \mathrm{c}$ & $2.69 \mathrm{c}$ & $0.80 \mathrm{~b}$ & 8.36 & $80.90 \mathrm{~b}$ & $341.52 \mathrm{c}$ \\
\hline & Pinha & $1.65 \mathrm{c}$ & $3.04 \mathrm{c}$ & $0.80 \mathrm{~b}$ & 7.24 & $81.76 \mathrm{~b}$ & $345.79 b$ \\
\hline & Red Yade & $1.31 \mathrm{c}$ & $3.15 \mathrm{c}$ & $0.72 b$ & 6.44 & $82.31 \mathrm{~b}$ & $348.33 b$ \\
\hline & Samura B. & $1.71 \mathrm{c}$ & $2.80 \mathrm{c}$ & $0.64 b$ & 7.29 & $81.67 \mathrm{~b}$ & $343.60 \mathrm{c}$ \\
\hline & Terra Anã Branca & $1.59 \mathrm{c}$ & $2.97 \mathrm{c}$ & $0.78 b$ & 9.32 & $79.58 \mathrm{c}$ & $337.22 \mathrm{c}$ \\
\hline & Terra Ponta Aparada & $1.84 \mathrm{c}$ & $3.52 \mathrm{~b}$ & $0.70 \mathrm{~b}$ & 4.18 & $84.80 \mathrm{a}$ & $360.17 \mathrm{a}$ \\
\hline & Terra Sem Nome & $1.52 \mathrm{c}$ & $3.30 \mathrm{c}$ & $1.15 \mathrm{a}$ & 8.53 & $78.70 \mathrm{c}$ & $337.86 \mathrm{c}$ \\
\hline & Tipo Velhaca & $1.51 \mathrm{c}$ & $2.71 \mathrm{c}$ & $0.62 b$ & 6.38 & $83.41 \mathrm{a}$ & $349.38 b$ \\
\hline & Trois Vert & $1.68 \mathrm{c}$ & $3.03 \mathrm{c}$ & $0.61 \mathrm{~b}$ & 6.17 & $82.93 \mathrm{a}$ & $349.31 \mathrm{~b}$ \\
\hline \multirow{3}{*}{$\begin{array}{l}\text { Commercial } \\
\text { Brazilian } \\
\text { plantains }\end{array}$} & Terra Maranhão & $1.86 \mathrm{c}$ & $3.30 \mathrm{c}$ & $0.78 b$ & 4.22 & $84.08 \mathrm{a}$ & $356.58 \mathrm{a}$ \\
\hline & D’Angola & $1.51 \mathrm{c}$ & $2.72 \mathrm{c}$ & $0.69 b$ & 6.36 & $83.01 \mathrm{a}$ & $349.17 b$ \\
\hline & Terrinha & $1.82 \mathrm{c}$ & $3.15 \mathrm{c}$ & $0.47 \mathrm{~b}$ & 11.84 & $78.19 \mathrm{c}$ & $329.63 \mathrm{~d}$ \\
\hline \multirow{5}{*}{$\begin{array}{l}\text { Commercial } \\
\text { Brazilian } \\
\text { dessert } \\
\text { bananas }\end{array}$} & BRS SCS Belluna & $3.34 \mathrm{a}$ & $4.18 \mathrm{a}$ & $1.11 \mathrm{a}$ & 18.79 & $67.46 \mathrm{e}$ & $296.51 \mathrm{e}$ \\
\hline & BRS Platina & $2.40 \mathrm{~b}$ & $3.53 b$ & $0.71 \mathrm{~b}$ & 7.65 & $76.66 \mathrm{~d}$ & $327.11 \mathrm{~d}$ \\
\hline & Grande Naine & $3.19 \mathrm{a}$ & $4.33 \mathrm{a}$ & $0.83 b$ & 8.37 & $77.62 \mathrm{~d}$ & $334.34 \mathrm{c}$ \\
\hline & Pacovan & $2.38 \mathrm{~b}$ & $2.84 \mathrm{c}$ & $0.62 b$ & 8.07 & $77.35 \mathrm{~d}$ & $326.32 \mathrm{~d}$ \\
\hline & Prata Anã & $2.53 \mathrm{~b}$ & $3.74 \mathrm{~b}$ & $0.71 \mathrm{~b}$ & 5.46 & $81.38 \mathrm{~b}$ & $346.85 b$ \\
\hline F-value & & $7.53 * *$ & $6.62 * *$ & $2.35 * *$ & - & $52.05^{* *}$ & $39.20 * *$ \\
\hline CV (\%) & & 18.33 & 9.99 & 23.63 & - & 1.17 & 1.14 \\
\hline
\end{tabular}

${ }^{(1)}$ Means followed by equal letters belong to the same group based on the Scott \& Knott test, at $5 \%$ probability. ${ }^{(2)}$ Data from a composite sample, with no statistical analysis. **Significant by the $\mathrm{F}$-test, at $1 \%$ probability. 
were processed at the same maturity stage and with the same parameters, the chemical composition of the assessed flours is due to genetic characteristics.

The principal component analysis was used to evaluate the differences among genotypes considering chemical characteristics. The two first principal components ( $\mathrm{PC} 1$ and $\mathrm{PC} 2$, respectively) explained $77.07 \%$ of the observed variation and, therefore, were selected to differentiate genotypes (Figure 1 A). Three

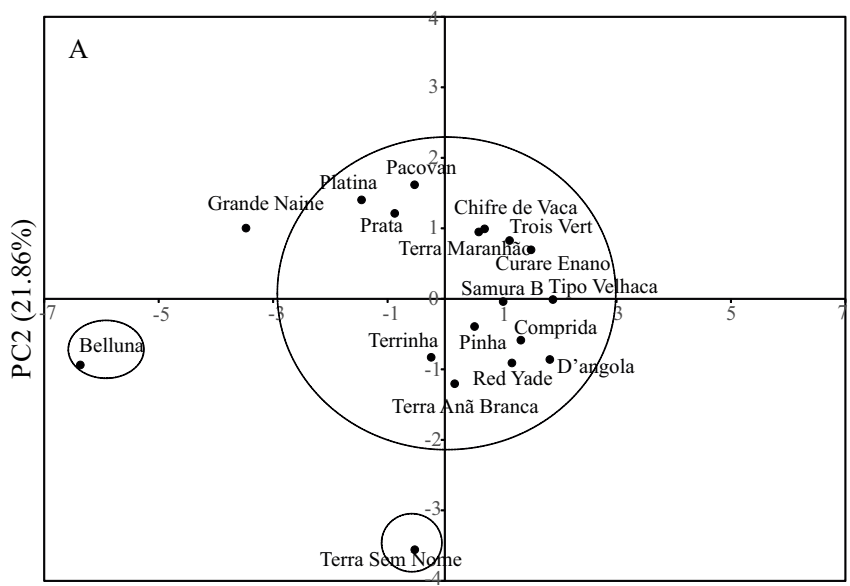

PC $1(55.21 \%)$

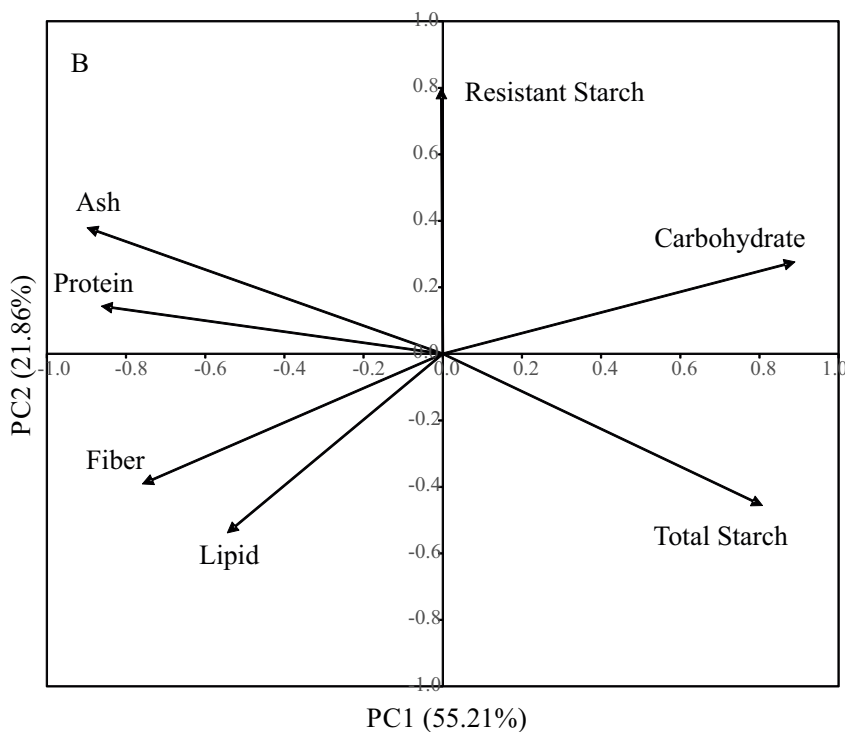

Figure 1. Principal component analysis of the flours produced from different banana and plantain genotypes, showing: A, the spatial distribution of the 20 evaluated flour samples in relation to the two first components; and B, correlations ("loadings") between the chemical characteristics of the flours and the two first components. groups were identified by the cluster analysis, and most of the plantains and dessert bananas formed one group with very similar chemical characteristics. The 'BRS SCS Belluna' dessert banana, located in the negative PC1 area, and the Terra Sem Nome plantain, located in the negative PC2 area, differed from each other and from the others.

PC1 was represented by carbohydrates (0.889), total starch (0.807), ash (-0.898), proteins $(-0.862)$, and fibers (-0.759) (Figure $1 \mathrm{~B})$, which differentiate genotypes in relation to the first principal component. The plantains, located in the positive PC1 area, were mainly characterized by high contents of carbohydrates and total starch. The 'BRS SCS Belluna' dessert banana, located in the negative PC1, was characterized by elevated ash, protein, and fiber contents, which differentiated this genotype from the others.

PC2 was represented by RS (0.799), and the plantain and dessert banana located in the positive PC2 area showed the highest contents. The Terra Sem Nome plantain, located in negative PC2 area, differed from the others and was characterized by a lower RS content (Table 2). Lipid content had a low correlation with PC1 (-0.544) and PC2 (-0.539), and, therefore, was not considered relevant to differentiate the evaluated genotypes. In a research conducted by Hoffmann Sardá et al. (2016), the following characteristics were considered relevant to distinguish green banana flours: RS (-0.746), dietary fiber (0.979), ash (0.949), and lipids (0.939); except for lipids, the remaining three characteristics were also important to differentiate genotypes in the present study. Gibert et al. (2009), in the component analysis, also concluded that the contents of starch, dry matter, and ash were relevant to differentiate bananas from plantains.

\section{Conclusions}

1. The Chifre de Vaca, Comprida, Trois Vert, and Terra Maranhão plantains are the best options to produce flour, considering flour yield, dry matter, and resistant starch contents.

2. The BRS SCS Belluna cultivar is a good option for producing flour richer in resistant starch, minerals, proteins and fibers, being interesting from a nutritional point of view. 


\section{Acknowledgments}

To Conselho Nacional de Desenvolvimento Científico e Tecnológico $(\mathrm{CNPq})$ and to Fundação de Amparo à Pesquisa do Estado da Bahia (Fapesb), for financial support and fellowships.

\section{References}

AGAMA-ACEVEDO, E.; ISLAS-HERNÁNDEZ, J.J.; PACHECO-VARGAS, G.; OSORIO-DÍAZ, P.; BELLO-PÉREZ, L.A. Starch digestibility and glycemic index of cookies partially substituted with unripe banana flour. LWT-Food Science and Technology, v.46, p.177-182, 2012. DOI: https://doi.org/10.1016/j. lwt.2011.10.010.

ANVISA. Agência Nacional de Vigilância Sanitária (Brasil). Resolução RDC $\mathbf{n}^{\circ}$ 54, de 12 de novembro de 2012. Dispõe sobre o Regulamento Técnico sobre Informação Nutricional Complementar. 2012. Available at: <http://portal.anvisa.gov.br/ documents/33880/2568070/rdc0054_12_11_2012.pdf/c5ac23fd974e-4f2c-9fbc-48f7e0a31864>. Accessed on: Nov. 42019.

ANYASI, T.A.; JIDEANI, A.I.O.; MCHAU, G.R.A. Effect of organic acid pretreatment on some physical, functional and antioxidant properties of flour obtained from three unripe banana cultivars. Food Chemistry, v.172, p.515-522, 2015. DOI: https://doi.org/10.1016/j.foodchem.2014.09.120.

BLIGH, E.G.; DYER, W.J. A rapid method of total lipid extraction and purification. Canadian Journal Biochemistry Physiological, v.37, p.911-917, 1959. DOI: https://doi.org/10.1139/ o59-099.

BORGES, A. de M.; PEREIRA, J.; LUCENA, E.M.P. de. Caracterização da farinha de banana verde. Ciência e Tecnologia de Alimentos, v.29, p.333-339, 2009. DOI: https://doi.org/10.1590/ S0101-20612009000200015.

BORGES, C.V.; MINATEL, I.O; AMORIM, E.P.; BELIN, M.A.F.; GOMEZ-GOMEZ, H.A.; CORREA, C.R.; LIMA, G.P.P. Ripening and cooking processes influence the carotenoid content in bananas and plantains (Musa spp.). Food Research International, v.124, p.129-136, 2019. DOI: https://doi.org/10.1016/j.foodres.2018.08.022.

DANIELLS, J.W. Bananas and plantains - the crops and their importance. In: CABALLERO, B. (Ed.). Encyclopedia of Food Sciences and Nutrition. $2^{\text {nd }}$ ed. [S.1.]: Academic Press, 2003. p.372-378.

DARAMOLA, B.; OSANYINLUSI, S.A. Production, characterization and application of banana (Musa spp) flour in whole maize. African Journal of Biotechnology, v.5, p.992-995, 2006.

FUENTES-ZARAGOZA， E.; RIQUELME-NAVARRETE, M.J.; SÁNCHEZ-ZAPATA, E.; PÉREZ-ÁLVAREZ, J.A. Resistant starch as functional ingredient: a review. Food Research International, v.43, p.931-942, 2010. DOI: https://doi.org/10.1016/j.foodres.2010.02.004.
GIBERT, O.; DUFOUR, D.; GIRALDO, A.; SÁNCHEZ, T.; REYNES, M.; PAIN, J.-P.; GONZÁLEZ, A.; FERNÁNDEZ, A.; DÍAZ, A. Differentiation between cooking bananas and dessert bananas. 1. Morphological and composition characterization of cultivated Colombian Musaceae (Musa sp.) in relation to consumer preferences. Journal of Agricultural and Food Chemistry, v. 57, p.7857-7869, 2009.

GONÇALVES, Z.S.; INVENÇÃO, D.R.S. da; LEDO, C.A. da S.; FERREIRA, C.F.; AMORIM, E.P. Agronomic performance of plantain genotypes and genetic variability using WardMLM algorithm. Genetics and Molecular Research, v.17, gmr16039882, 2018. DOI: https://doi.org/10.4238/gmr16039882.

GOÑI, I.; GARCÍA-DIZ, L.; MAÑAS, E.; SAURA-CALIXTO, F. Analysis of resistant starch: a method for foods and food products. Food Chemistry, v.56, p.445-449, 1996.

HOFFMANN SARDÁ, F.A.; LIMA, F.N.R. de; LOPES, N.T.T.; SANTOS, A. de O.; TOBARUELA, E. de C.; KATO, E.T.M.; MENEZES, E.W. Identification of carbohydrate parameters in commercial unripe banana flour. Food Research International, v.81, p.203-209, 2016. DOI: https://doi.org/10.1016/j. foodres.2015.11.016.

LATIMER JR., G.W. (Ed.). Official Methods of Analysis of the AOAC International. $19^{\text {th }}$ ed. Gaithersburg: AOAC International, 2012.

MENEZES, E.W.; TADINI, C.C.; TRIBESS, T.B.; ZULETA, A.; BINAGHI, J.; PAK, N.; VERA, G.; DAN, M.C.T.; BERTOLINI, A.C.; CORDENUNSI, B.R.; LAJOLO, F.M. Chemical composition and nutritional value of unripe banana flour (Musa acuminata, var. Nanicão). Plant Foods for Human Nutrition, v.66, p.231-237, 2011. DOI: https://doi.org/10.1007/s11130-0110238-0.

MESQUITA, C. de B.; LEONEL, M.; FRANCO, C.M.L.; LEONEL, S.; GARCIA, E.L.; SANTOS, T.P.R. dos. Characterization of banana starches obtained from cultivars grown in Brazil. International Journal of Biological Macromolecules, v.89, p.632-639, 2016. DOI: https://doi.org/10.1016/j.ijbiomac.2016.05.040.

MOTA, R.V. da; LAJOLO, F.M.; CIACCO, C.; CORDENUNSI, B.R. Composition and functional properties of banana flour from different varieties. Starch/Stärke, v.52, p.63-68, 2000. DOI: https://oi.org/10.1002/(sici)1521-379x(200004)52:2/3<63::aidstar63>3.0.co;2-v.

RICKARD, J.E.; BEHN, K.R. Evaluation of acid and enzyme hydrolitic methods for the determination of cassava starch. Journal of the Science of Food and Agriculture, v.41, p.373-379, 1987. DOI: https://doi.org/10.1002/jsfa.2740410409.

SARAWONG, C.; SCHOENLECHNER, R.; SEKIGUCHI, K.; BERGHOFER, E.; NG, P.K.W. Effect of extrusion cooking on the physicochemical properties, resistant starch, phenolic content and antioxidant capacities of green banana flour. Food Chemistry, v.143, p.33-39, 2014. DOI: https://doi.org/10.1016/j. foodchem.2013.07.081.

SAVLAK, N.; TÜRKER, B.; YESILKANAT, N. Effects of particle size distribution on some physical, chemical and functional 
properties of unripe banana flour. Food Chemistry, v.213, p.180186, 2016. DOI: https://doi.org/10.1016/j.foodchem.2016.06.064.

SEGUNDO, C.; ROMÁN, L.; GÓMEZ, M.; MARTÍNEZ, M.M. Mechanically fractionated flour isolated from green bananas $(M$. cavendishii var. nanica) as a tool to increase the dietary fiber and phytochemical bioactivity of layer and sponge cakes. Food Chemistry, v.219, p.240-248, 2017. DOI: https://doi.org/10.1016/j. foodchem.2016.09.143.

SILVA, A. dos A.; BARBOSA JUNIOR, J.L.; BARBOSA, M.I.M.J. Farinha de banana verde como ingrediente funcional em produtos alimentícios. Ciência Rural, v.45, p.2252-2258, 2015. DOI: https://doi.org/10.1590/0103-8478cr20140332.

THAKORLAL, J.; PERERA, C.O.; SMITH, B.; ENGLBERGER, L.; LORENS, A. Resistant starch in Micronesian banana cultivars offers health benefits. Pacific Health Dialogue, v.16, p.49-59, 2010 .

VATANASUCHART, N.; NIYOMWIT, B.; WONGKRAJANG, $\mathrm{K}$. Resistant starch contents and the in vitro starch digestibility of
Thai Starchy Foods. Kasetsart Journal: Natural Science, v.43, p.178-186, 2009.

VERNAZA, M.G.; GULARTE, M.A.; CHANG, Y.K. Addition of green banana flour to instant noodles: rheological and technological properties. Ciência e Agrotecnologia, v.35, p.1157-1165, 2011. DOI: https://doi.org/10.1590/S1413-70542011000600016.

WROLSTAD, R. e; SMITH, D.E. Color analysis. In: NIELSON, S.S. (Ed.). Food Analysis. $4^{\text {th }}$ ed. New York: Springer, 2010. p.573-586. DOI: https://doi.org/10.1007/978-1-4419-1478-1_32.

YANI, A.; ARIEF, R.W.; MULYANTI, N. Processing of banana flour using a local banana as raw materials in Lampung. International Journal on Advanced Science, Engineering and Information Technology, v.3, p.26-30, 2013. DOI: https://doi.org/10.18517/ijaseit.3.4.306.

ZENEBON, O.; PASCUET, N.S.; TIGLEA, P. (Coord.). Métodos físicos-químicos para análise de alimentos. 4.ed. São Paulo: Instituto Adolfo Lutz, 2008.1020p. 